\title{
Aggrandizement in the Performance of Double slope Solar Still with the Incorporation of Peltier Effect in Addition To Water Depths
}

\author{
Vivek Natarajan. S, Vivekanandhan. B, Armstrong. M
}

\begin{abstract}
Because of continuous increment in the world population and pollution, the scarcity of water has been increasing constantly. Many researchers are doing research in the field of desalination to convert the impure or soar water into drinkable water. Even though many methodologies were followed, desalination using solar still is the oldest and less cost concept with higher lifetime. So research in this field is still undergoing by enhancing the distillate production by incorporating advanced technologies, by controlling the factors affecting the distillate production and introducing various designs. In this work, the double slope solar still had been used and the performance was found at $1 \mathrm{~cm}$ and $0.5 \mathrm{~cm}$ water depth. In addition to that, the introduction of Peltier module in the back side of the absorber plate had been fixed to generate the electricity during the day time due to the temperature difference in the Peltier module to charge the battery. The stored current is again used to activate the Peltier to increase the heat generation during the evening time. The performance was increased in both $1 \mathrm{~cm}$ water depth and 0.5 water depth by $13 \%$ and $9.1 \%$ respectively during the heating period in the evening hours.
\end{abstract}

Keywords-double slope solar still, Peltier module, distillate enhancement.

\section{INTRODUCTION}

$\mathbf{N}$ industrialization and high population. Water scarcity not only means inadequate fresh water. But also the inefficacy of the government to supply water in a regular manner to the common people. Already more continents in the globe were affected due to water scarcity. As per the survey taken by UN, 2018 (1) and Global Water Institute, 2013 (2) maximum of 2 billion people are suffering a high water stress in a countries and 700 million people worldwide could caught high water scarcity by 2030 . This might also due to the boom of modern products for higher luxury life style and industrial usage, by wasting more amount of fresh water. Since it is cheapest and easily available raw material. Hence this serious problem could be control by using an attractive (3) and cost effective method (4) to recycle the waste or saline water into fresh water is solar distillation method. This

Revised Manuscript Received on December 30, 2019.

* M. Armstrong

Vivek Natarajan. S*, Department of Mechanical Engineering, Kalasalingam Academy of Research and Education, Krishnankovil, India. Email: viveknatarajan.vs@gmail.com

Vivekanandhan. B, Department of Mechanical Engineering, Kalasalingam Academy of Research and Education, Krishnankovil, India Email: vivekanandhan5398@gmail.com

Armstrong. M, Department of Mechanical Engineering, Kalasalingam Academy of Research and Education, Krishnankovil, India. Email: armstrong@klu.ac.in owadays the scarcity of water increased due to the

method is environment-friendly since sunlight does not harm and it is having abundant energy. Researchers are working on the enhanced modern solar still by introducing many tools. Since the working efficiency of existing solar still model is very low. The main intension of this work is to develop a new modern technique and non-technical tool to improve the working efficiency of the solar still. So a new kind of low cost Peltier module (5) is introduced in the backside of the absorber plate to enhance the performance of the absorber plate and the solar still which would increase the efficiency of the system by increasing the distillate production. The Peltier module is a rectangular plate consists of semiconducting material with hot and cold junction. This converts the electrical energy into heat energy as a hotness and coldness in either side of the plate (10). Because of this principle, it had been used in many applications nowadays. Amine Allouhi et al (5) stated that the collective work of thermal power and electric power from the thermoelectric system in the solar applications generates improved performance in addition to the solar irradiation. Javad Abolfazli Esfahani et al (4) discussed the utilization of the new designed portable solar still with thermoelectric system for cooling the vapour had been studied. Since during the winter season, the wind velocity was high compared to summer, so as to enhance the evaporation rate, the thermoelectric generator was used and it enhances the condensation rate of evaporated vapor through cooling process. V. P. Joshi et al (6) experimented the conversion of atmospheric air into water particles through cooling process using the thermoelectric cooler. Hayder Al-Madhhachi et al (7) experimentally studied the main factors influencing the water formation using thermoelectric distillation system and had been stating that the Peltier current and its input, water temperature, and vapour volume decides the distillation of vapour. The higher water production could be attained by maintaining the lower condenser temperature through the controlled supply of thermal energy from the Peltier module as an output and current as an input. P. Pounraj et al (9) discussed that Peltier cooling and heating effect over the glass plate provided $52 \%$ thermal efficiency compared to the normal solar still and 30\% while using solar photo voltaic cell. It attained 6.5 times enhanced water productivity compared to normal still. Amir Hossein Shourideh (11) discussed that the current input to the Peltier increases the cooling effect and increases the water formation was found.

In this work the Peltier modules had been placed below the absorber plate to produce the electricity during the day time due to the temperature difference between the two sides. The generated electricity is used for heating the plate during the evening hours by supplying energy from the charged battery. 


\section{Aggrandizement in the Performance of Double slope Solar Still with the Incorporation of Peltier Effect in Addition To Water Depths}

This process and setup enhanced the performance of the solar still by producing high vapour inside the solar still without much energy wastage and the performance was higher during the evening hours compared to conventional solar still.

\section{METHODS AND METHODOLOGY}

The experiment had been carried out in the Virudhunagar district, South Tamilnadu with the latitude of $9.5747^{\circ} \mathrm{N}$, $77.6798^{\circ} \mathrm{E}$. The solar still consist of flat absorber plate coated with black paint, transparent glasses, thick wooden box and thermocol for insulation, sealant, condensate channel, storage tank, Peltier module. The transparent glasses are fixed with the angle of $26^{\circ}$ to the wooden box and faced south to absorb a maximum solar radiation into the system. The experiment was conducted in the month of March and April. The Peltier modules were attached to the bottom of the absorber plate connected to the $12 \mathrm{~V} \mathrm{DC}$ battery. Hot side facing the plate and cold side facing the atmosphere. The experiment had been carried out with the depth of $1 \mathrm{~cm}$ and $0.5 \mathrm{~cm}$ to check the maximum productivity rate compared to the normal solar still. The sun radiation falling inside the solar still over the flat absorber plate with the brackish water absorb the heat through the transparent glasses. Due to the temperature difference, the evaporation takes place and the evaporated vapour condensed in the inner glass plate and gets collected in the distillate collector through the condensate channel.

\section{A. Design of the still and Specifications}

TABLE 1. Technical Specifications of solar still

\begin{tabular}{|r|l|c|}
\hline S.No & \multicolumn{2}{|c|}{ Design Parameters } \\
\hline 1. & Basin area & $1 \mathrm{~m}^{2}$ \\
\hline 2. & Angle of glazing & $26^{\circ}$ \\
\hline 3. & Thickness of glass plate & $0.002 \mathrm{~m}$ \\
\hline 4. & Thickness of Stainless steel & $0.002 \mathrm{~m}$ \\
\hline 5. & $\begin{array}{l}\text { Thickness } \\
\text { insulation(wood) }\end{array}$ & $0.010 \mathrm{~m}$ \\
\hline 6. & Thickness of thermocol & $0.02 \mathrm{~m}$ \\
\hline 7. & Emissivity of glass & 0.94 \\
\hline 8. & Emissivity of water & 0.96 \\
\hline 9. & Latent heat of vaporization & $2382.9 \mathrm{~kg} / \mathrm{m}^{3}$ \\
\hline 10. & Density of Stainless steel & $7700 \mathrm{~kg} / \mathrm{m}^{3}$ \\
\hline
\end{tabular}
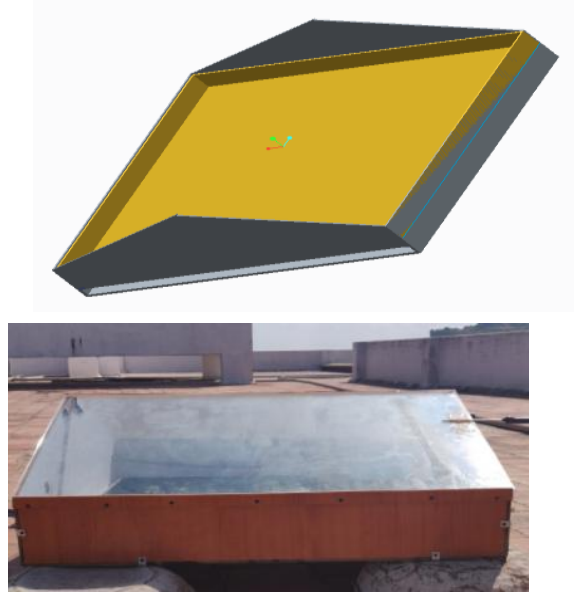

B. Instruments used to measure

\begin{tabular}{|c|c|c|}
\hline S.No & Instruments used & Range \\
\hline 1.1 & Digital thermometer & $-50^{\circ} \mathrm{C}-300^{\circ} \mathrm{C}$ \\
\hline 2. & $\begin{array}{c}\text { Sola power meter } \\
(\mathrm{TM}-207)\end{array}$ & $\begin{array}{c}0.1-2000 \mathrm{~W} / \mathrm{m}^{2} /+/- \\
10 \mathrm{~W} / \mathrm{m}^{2}\end{array}$ \\
\hline 3. & $\begin{array}{c}\text { Peltier module } \\
(\mathrm{TEC} 1-2706)\end{array}$ & $-30^{\circ}-70^{\circ} \mathrm{C} / 12 \mathrm{~V} 60 \mathrm{~W}$ \\
\hline 4. & Multi meter(DT9205A) & $10 \mathrm{~A} / 500 \mathrm{~V}$ \\
\hline 5. & Battery & $12 \mathrm{~V}$ \\
\hline
\end{tabular}

\section{EXPERIMENTAL PROCEDURE}

The experimental setup of the solar still possesses brackish water settled in the black coated stainless steel basin flat plate. The setup is completely insulated by wood, thermocol and the sealant tape to reduce the heat release from the still to the surrounding. The transparent glazing had been given over the still to make the solar radiation to fall inside the basin and not to escape from the basin. It had been faced south and north to trap maximum solar radiation. The four Peltier modules had placed below the flat absorber plate to produce current in the peak days and to heat the basin during the evening hours.

The experiment had been conducted in the month of April at the location of Virudhunagar $\left(9.5747^{\circ} \mathrm{N}, 77.6798^{\circ} \mathrm{E}\right)$. A fine weather climatic condition had been chosen for validating the experiment. The temperatures of water, two glasses, flat absorber plate and dry, wet conditions of air have been measured using digital thermometers and psychrometer respectively. The solar radiation had been measured using the solar power meter. The Peltier module is powered with the battery and the current produced is measured with the help of multimeter. The water level had been maintained with the 0.5 $\mathrm{cm}$ depth and $1 \mathrm{~cm}$ depth and the readings had been taken for a continuous week respectively. When the solar radiation fall inside the solar still heats up the plate and water by increasing the temperature and pressure inside the still and made the water to evaporate. Then the evaporated vapour reaches the glass and due to the cover it strikes and reduces its energy by giving to glasses and gets condensed over the glass and get collected in the collector through the condensate channel. The collected water is measured in the beaker. The readings have been taken from 9.00 am to $18.00 \mathrm{pm}$ for a week for $0.5 \mathrm{~cm}$ depth and for $1 \mathrm{~cm}$ depth. The validation had been taken for the days where the solar radiation was taken nearer values and the results had been discussed.

\section{RESULTS AND DISCUSSION}

\section{A. Influence of solar radiation with respect to time}

The solar radiation from the sun varies from day to day depends upon the moisture present in the clouds, greenhouse gases, and air velocity. Since it is of two types direct radiation and diffused radiation. The amount of distillate production is directly proportional to the solar irradiance. During experimentation process, the solar radiations were varied differently in each day. The measurements had been taken for every one hour from 9.00 am to $18.00 \mathrm{pm}$.

Fig. 1. 3 D and Experimental setup of a solar still 
The solar radiation started with the minimum value and then reached a maximum of $1010 \mathrm{~W} / \mathrm{m}^{2}$ during the peak hours. This made a high yield during the peak hours compared to the evening and morning hours. Due to the sun geometry, the transparent glass faced south got high radiation compared to the north faced transparent glass. Hence after comparison between two weeks of measurement for $0.5 \mathrm{~cm}$ and $1 \mathrm{~cm}$ depth, particular days were found nearer values and the validations were predicted. From the Fig 2, we could identify that the measurements of 17.04.19 and 25.04.19 are moreover same and the ambient temperature also measured and got the nearby values. But there were some fluctuations in the wind velocity.

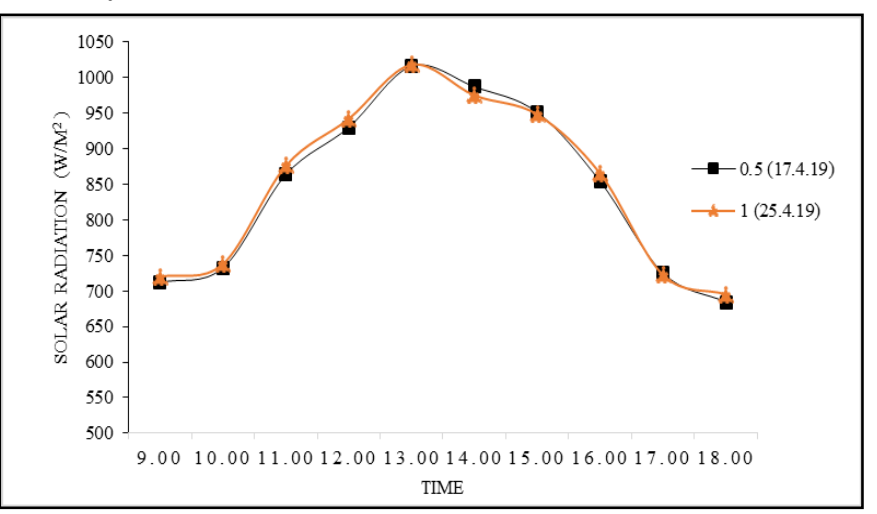

. Fig. 2. Solar radiation Vs Time

B. Influence of water, basin, glass and ambient temperatures with respect to time

During experimentation, the temperatures of water $\left(\mathrm{T}_{\mathrm{w}}\right)$, basin $\left(\mathrm{T}_{\mathrm{a}}\right)$, glass $\left(\mathrm{T}_{\mathrm{gm}}\right)$, vapour $\left(\mathrm{T}_{\mathrm{v}}\right)$ and ambient temperatures were measured. It gradually increases from the morning hours and attain maximum in the peak hours and decreases again in the low sunlight. Here the basin temperature and water temperature influence the rate of evaporation and glass temperature influences the rate of condensation of the vapour. Hence the glass temperature had been maintained by spraying the water over the glass. This reduces the temperature of glass and increases the condensate rate. The ambient temperature and wind velocity played a significant role in the production of vapor by increasing or decreasing the temperature inside the system".

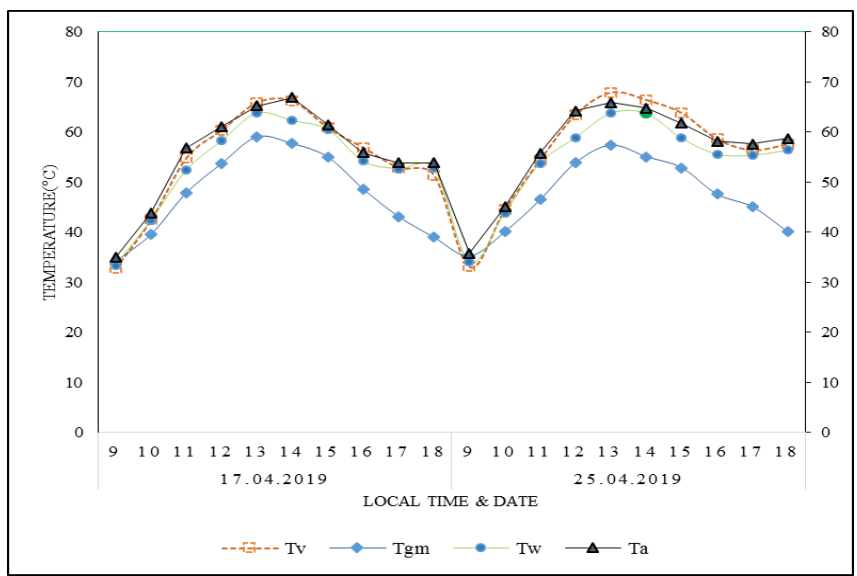

Fig. 3. Temperatures of water, glass, absorber plate and vapour vs Time

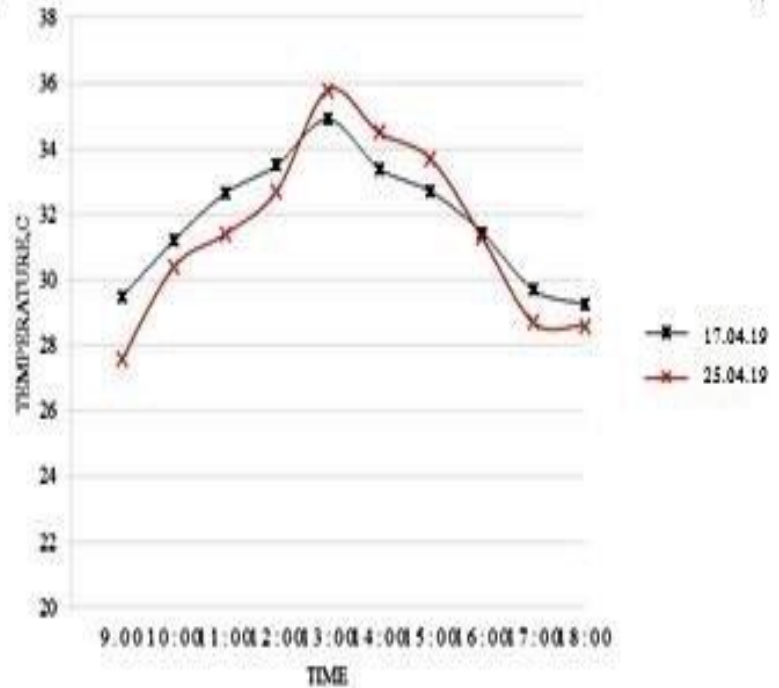

Fig. 4. Ambient Temperature Vs Time

\section{Influence of Peltier effect and distillate production}

As the distillate production mainly depends on the solar radiation, temperatures of the basin vapour and water. The hourly based distillate readings showed the increment and decrement based on the above said factors. Hence during low light conditions like evening hours, the Peltier module energized and heats the plate to increase the basin and water temperature which would automatically enhance the evaporation and condensate rate. This would reflect in the result which obtained during the measurement in the low light condition. There we found a increase in the distillate formation. Hence the active involvement of peltier also enhances the hourly and total production rate of the distillate. The energy for the Peltier module is given by the energy stored in the battery during the peak hours by keeping the hot surface in the heating plate and cold surface at the atmospheric conditions.

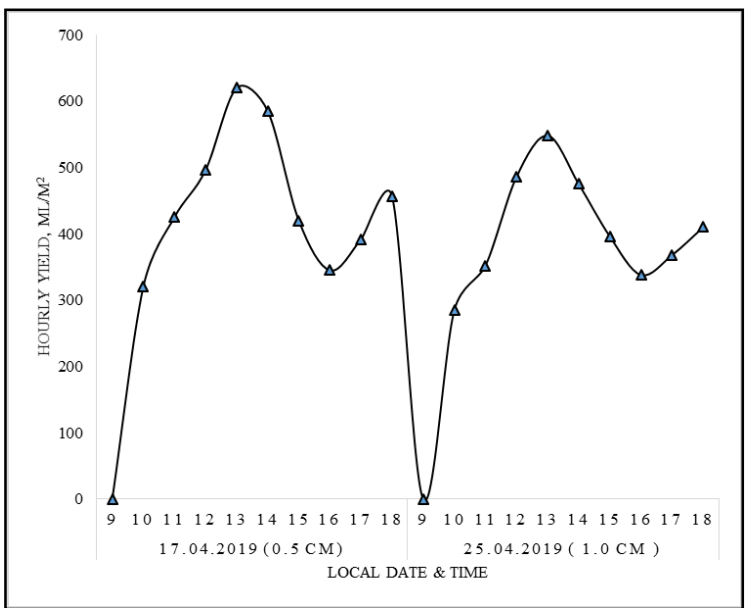

Fig. 5. Hourly productions of distillate vs Time 


\section{Addition To Water Depths}

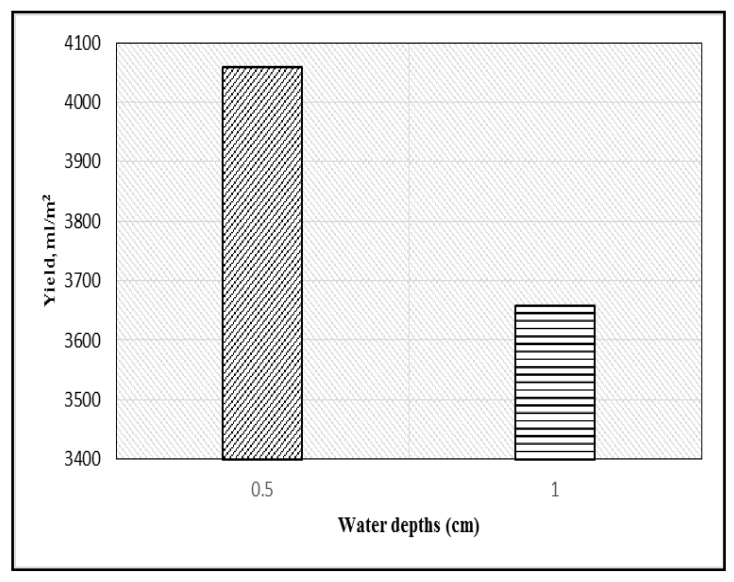

Fig. 6. Yield vs Water depth

\section{CONCLUSION}

In this work, the enhancement of distillate production using the double slope solar still had been experimentally studied using the Peltier module as a heating and power generating device with the different depths attained the following conclusions.

1. The experimental investigation from the results proved again that the low level water depths $(0.5 \mathrm{~cm})$ had higher distillate production compared to the higher depths $(1 \mathrm{~cm})$. But with adding Peltier effect it gave higher water production comparing to the conventional double slope solar still.

2. Peltier module generated the voltage of $3-5 \mathrm{~V}$ during the low temperature to the higher temperature difference and it as a heating module, it enhances the generation of the temperature and distillate production by $11 \%$ in the $0.5 \mathrm{~cm}$ water depth and $8.5 \%$ increment in the $1 \mathrm{~cm}$ water depth for every hour during the heating period of $16.00 \mathrm{pm}$ to $18.00 \mathrm{pm}$. These results state that usage of Peltier modules in the low water depth could give an enhanced distillate production comparing to the conventional solar stills. Nowadays these kinds of research works could pave a path way for a new idea in the production of modern and compact solar stills by designing and implementing with Peltier modules. In future, it would play a predominant role and provides a step ahead in the research field of double slope solar still fresh water conversion.

\section{REFERENCES}

1. UN 2018: SDG 6 Synthesis Report.

2. World Resources Institute: Blog: What we know about water scarcity.

3. N. Rahbar, J.A. Esfahani, "Experimental study of a novel portable solar still by utilizing the heatpipe and thermoelectric module," Desalination 284 (2012) 55-61.

4. Javad Abolfazli Esfahani, Nader Rahbar, Mehdi Lavvaf, "Utilization of thermoelectric cooling in a portable active solar still - An experimental study on winter days", Desalination 269 (2011) 198-205.

5. Amine Allouhi, "Advances on solar thermal cogeneration processes based on thermoelectric devices: A review," Solar Energy Materials and Solar Cells 200 (2019) 109954

6. V. P. Joshi, V. S. Joshi, H. A. Kothari, M. D. Mahajan, M. B. Chaudhari, K. D. Sant, "Experimental investigations on a portable fresh water generator using a thermoelectric cooler," Energy Procedia 109 ( 2017 ) $161-166$.

7. Hayder Al-Madhhachi, Gao Min, "Key factors affecting the water production in a thermoelectric distillation system," Energy Conversion and Management 165 (2018) 459-464.

8. A. Allouhi, A. Boharb, T. Ratlamwala, T. Kousksou, M.B. Amine, A. Jamil, A.A. Msaad, "Dynamic analysis of a thermoelectric heating system for space heating in a continuous-occupancy office room", Appl. Therm. Eng. 113 (2017).

9. P. Pounraj, D. Prince Winston, A.E. Kabeel, B. Praveen Kumar, A. Muthu Manokar, Ravishankar Sathyamurthy, S. Cynthia Christabel," Experimental investigation on Peltier based hybrid PV/T active solar still for enhancing the overall performance", Energy Conversion and Management 168 (2018) 371-381.

10. Amir Hossein Shourideh, Wael Bou Ajram, Jalal Al Lami, Salem Haggag, Abraham Mansouri." A Comprehensive Study of an Atmospheric Water Generator using Peltier Effect", Thermal Science and Engineering Progress (2018).

11. N. Rahbar, J.A. Esfahani," Experimental study of a novel portable solar still by utilizing the heatpipe and thermoelectric module," Desalination 284 (2012) 55-61.

12. M.M. Morad, Hend A.M. El-Maghawry, Kamal I. Wasfy," A developed solar-powered desalination system for enhancing fresh water productivity", Solar Energy 146 (2017) 20-29.

13. B.SelvaKumar, Sanjay Kumar, R. Jayaprakasha) 'Performance analysis of a " $v$ " type solar still using a charcoal absorber', Desalination229 (1-3), 2007, 217-230.

14. Chandrasekhar M, Avadheh Yadav, 'Water desalination system using solar heat', Desalination 156(1-3) 2017, 323-332.

15. Gerald R. Ginn. 'Filed test evaluation of solar heated evaporators', journal of solar energy engineering 114(3), (2002), 165-170

16. Hikmet.S Aybar, Fuat Egeliofglu, U. Atikol An experimental study on an inclined solar water distillation system', Desalination 180(1-3), (2005), 285-289

17. Joachim Koschikowski, Marcel Wieghaus, Matthias Rommel, 'Solar thermal-driven desalination plants based on membrane distillation', desalination 156(1-3), ,(2003), 295-304.

18. M. Vivar, I. Skryabin, V. Everett, A. Blakers, 'concept for a hybrid solar water Purification and photovoltaic system', Solar Energy Materials and Solar Cells 94(10), (2010), 1772-1782.

19. S.Al-kharabsheh, Yogi goswami 'An experimental study on an inclined solar water distillation system, utilizing a passive vacuum technique' Desalination 180(1- 3), (2003) 285-289.

20. Ahmed Z Al-Garni, Ayman H Kaseem, Farooq Saeed and Faizan Ahmed, Effect of Glass Slope Angle and Water Depth on Productivity of Double Slope Solar Still, Journal of Scientific and Industrial Research, Vol.70, 2011, pp. 884-890.

21. Hiroshi Tanaka and Yuh-Shan Ho, Global trends and performances of desalination research, Desalination Publications, 2011, pp. 1-12.

22. O.A Ighodalo and F.A. Ebhodaghe, Performance Evaluation of a Solar Still for Salty Water Desalination, Journal of Emerging Trends in Engineering and Applied Sciences (JETEAS), Vol.2, 2011, , pp. 338-341.

23. K.L. Katsifarakis, Solar distillation treatment of landfill leachate. A case study in Greece, Desalination 94, 1993, pp. 213-221.

24. Y. P. Yadav and A. S. Prasad, Performance Analysis of a High Temperature Solar Distillation System, Energy Conservation and Mgmt, Vol. 36, No. 5, 1995, pp. 365-374.

25. G.N. Tiwari, H.N. Singh and Rajesh Tripathi, Present status of solar distillation, Solar Energy 75, 2003, pp.367-373.

26. M. A. Farwati, Theoretical Study Of Multi-stage Flash Distillation Using Solar Energy, Energy, Vol. 22, No. 1, 1997, pp. I-5.

27. Hassan E.S. Fath, Solar distillation: a promising alternative for water provision with free energy, simple technology and a clean environment, Desalination 116, 1998, pp. 45-56.

28. Siaka Toure, Hassan Salami and Pierre Meukam, Theoretical and Experimental Studies of a Solar Still Type Suitable for Alcoholic Distillation, Renewable Energy 16, 1999, pp. 739-742.

29. Lilian Malaeba, George M. Ayoubb and Mahmoud Al-Hindic, The Effect of Cover Geometry on the Productivity of a Modified Solar Still Desalination Unit, Energy Procedia 50, 201, pp. $406-413$.

30. V.K. Dwivedi and G.N. Tiwari, Experimental validation of thermal model of a double slope active solar still under natural circulation mode, Desalination 250, 2010, pp. 49-55.

31. Lourdes Garcia-Rodriguez and Carlos Gomez-Camacho, Perspectives of solar-assisted seawater distillation, Desalination 136,2001, pp. 213-218. 
32. Soteris A. Kalogiro, Solar Thermal Collectors and Applications, Progress in Energy and Combustion Science 30, 2004, pp. 231-295.

33. Hossein Taghvaei, Hamed Taghvaei, Khosrow Jafarpur, M.R. Karimi Estahbanati, Mehrzad Feilizadeh, Mansoor Feilizadeh and A. Seddigh Ardekani, A thorough investigation of the effects of water depth on the performance of active solar stills-Desalination 347,2014, pp. 77-85.

34. Ali.F.Muftah, M.A.Alghouln, AhmadFudholi, M.M.Abdul-Majeed and K.Sopian, Factors affecting basin type solar still productivity: A detailed review- Renewable and Sustainable Energy Reviews 32, 2014, pp. 430-447.

35. T. Rajaseenivasan, K. Kalidasa Murugavel, Theoretical and experimental investigation on double basin double slope solar still-Desalination 319, 2013, pp. 25-32.

36. Jianyin Xiong, Guo Xie, Hongfei Zheng-Experimental and numerical study on a new multi-effect solar still with enhanced condensation surface-Energy Conversion and Management 73,2013, , pp. 176-185.

37. M.T Chaibi, Thermal Solar Desalination Technologies for Small-Scale Irrigation-American Journal of Energy Research, Vol. 1, No. 2,2013, pp. 25-32.

38. T. Rajaseenivasan, K.KalidasaMurugaveln, T.Elango and R.Samuel Hansen, A review of different methods to enhance the productivity of the multi-effect solar still, Renewable and Sustainable Energy Reviews 17, 2013 , pp. 248-259. 